CLINICAL STUDY

\title{
Can basal cortisol measurement be an alternative to the insulin tolerance test in the assessment of the hypothalamic-pituitary- adrenal axis before and after pituitary surgery?
}

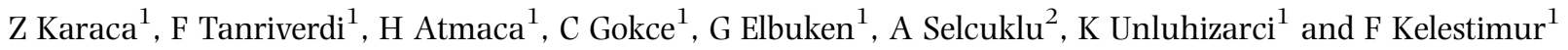 \\ Departments of ${ }^{1}$ Endocrinology and ${ }^{2}$ Neurosurgery, Erciyes University Medical School, 38039 Kayseri, Turkey \\ (Correspondence should be addressed to F Kelestimur; Email: fktimur@erciyes.edu.tr)
}

\begin{abstract}
Background: The aims of this study were to evaluate the validity of preoperative basal serum cortisol levels measured in predicting preoperative adrenal insufficiency and also the validity of basal serum cortisol levels and early postoperative insulin tolerance test (ITT) in predicting postoperative adrenal insufficiency.

Methods: The study was prospectively designed and included 64 patients who underwent pituitary surgery for conditions other than Cushing's disease. An ITT was performed preoperatively, on the 6th postoperative day and at the 1st postoperative month. Basal serum cortisol levels were measured on the $2 \mathrm{nd}$, 3rd, 4th, 5th, and 6th postoperative days.

Results: Patients with a preoperative basal cortisol level of $<165 \mathrm{nmol} / \mathrm{l}(6 \mu \mathrm{g} / \mathrm{dl})$ showed insufficient cortisol response and those with levels higher than $500 \mathrm{nmol} / \mathrm{l}(18 \mu \mathrm{g} / \mathrm{dl})$ had sufficient cortisol response to the preoperative ITT. The positive predictive value of the ITT performed on the 6th postoperative day was $69.7 \%$, and the negative predictive value in predicting adrenal insufficiency at the 1 st postoperative month was $58 \%$. Patients were considered to have an insufficient cortisol response to ITT at the 1st postoperative month if their basal cortisol levels were $<193 \mathrm{nmol} / \mathrm{l}(7 \mu \mathrm{g} / \mathrm{dl})$ or $220 \mathrm{nmol} / \mathrm{l}(8 \mu \mathrm{g} / \mathrm{dl})$ or $193 \mathrm{nmol} / \mathrm{l}(7 \mu \mathrm{g} / \mathrm{dl})$ or $165 \mathrm{nmol} / \mathrm{l}(6 \mu \mathrm{g} / \mathrm{dl})$ or $83 \mathrm{nmol} / \mathrm{l}(3 \mu \mathrm{g} / \mathrm{dl})$ on the 2nd-6th postoperative days respectively.

Conclusion: Serum basal cortisol levels may be used as the first-line test in the assessment of the hypothalamic-pituitary-adrenal axis both preoperatively and postoperatively. Dynamic testing should be limited to the patients with indeterminate basal cortisol levels.
\end{abstract}

European Journal of Endocrinology 163 377-382

\section{Introduction}

Controversy exists regarding hypothalamic-pituitaryadrenal (HPA) axis evaluation and glucocorticoid replacement around the time of pituitary surgery. The insulin tolerance test (ITT) is the gold standard test for examining HPA axis function (1-3). It is used in the preoperative and postoperative assessment of patients with pituitary adenoma.

The HPA axis may also be evaluated by other tests, such as the ACTH (1 and $250 \mu \mathrm{g}$ ACTH 1-24), metyrapone, glucagon, and CRH stimulation tests. There are several advantages to using ITT compared with other tests. The entire HPA axis can be evaluated in addition to the $\mathrm{GH}$ and insulin-like growth factor 1 axis, and cortisol responses to ITT are reproducible in normal subjects $(4,5)$. But there are some disadvantages; ITT is unpleasant for patients and close medical supervision is required during the test. It is contraindicated in patients with ischemic heart disease, arrhythmia, or epilepsy, and should be used in older patients with caution.
The disadvantages of ITT raise the question whether basal serum cortisol can be used as a first step in the assessment of HPA axis integrity with optimal cut-off levels, and limit the number of patients undergoing dynamic testing.

Postoperative basal cortisol level has previously been compared with cortisol response to the ACTH stimulation test and ITT in predicting postoperative adrenal insufficiency. Different cortisol cut-off levels have been suggested for the 5th or 6th-7th postoperative days according to the ITT at the 4th or 6th postoperative week (6-8). In one study, the concordance of low and standard dose ACTH stimulation tests and ITT in the early postoperative period with a third month postoperative ITT was examined in 19 patients, and early postoperative dynamic tests were considered to be useless (9).

The aims of this study were to evaluate the validity of preoperative basal serum cortisol levels in predicting preoperative adrenal insufficiency and also the validity of basal serum cortisol levels and early postoperative 
ITT in predicting postoperative adrenal insufficiency. If a cut-off level for basal cortisol can be determined, ITT might be avoided in at least some patients both preoperatively and/or postoperatively, and glucocorticoid replacement could be considered according to basal cortisol levels.

\section{Patients and methods}

\section{Patients}

This study was prospectively designed and included 64 patients (32 female and 32 male, age: 18-72 years, mean age: $42.9 \pm 12.8$ years) who underwent pituitary surgery for conditions other than Cushing's disease; 25 (39.1\%) patients had nonfunctional, 28 (43.7\%) had GH secreting, $10(15.6 \%)$ had prolactin-secreting pituitary adenomas, and 1 (1.6\%) had craniopharyngioma.

\section{Study protocol}

Patients were operated on by the same neurosurgeon (A S). Basal pituitary hormone levels were measured in all patients preoperatively and postoperatively on the 6th day and at 1 month. An ITT was performed preoperatively on all patients except on nine patients who were in urgent need of pituitary surgery. Basal serum cortisol levels were measured on the $2 \mathrm{nd}$, 3rd, 4th, 5th, and 6th postoperative days. An ITT was repeated on the 6 th postoperative day and at 1 month. None of the patients had hypoalbuminemia or had been treated with estrogens that could affect the measurement of serum cortisol.

A 25-mg dose of prednisolone was given on the day of operation, and a further $25 \mathrm{mg}$ i.v. just before anesthesia induction to patients with secondary adrenal insufficiency which had been detected preoperatively. The other patients underwent the operation under close supervision without glucocorticoid administration. After performing the ITT on the 6th postoperative day, patients were followed up by close clinical supervision in the 1st postoperative month, and replacement therapy was planned according to the results of the ITT at 1 month.

The ITT was performed after an overnight fast, starting at 0800-0900 h. Peripheral venous blood samples were obtained before the test and after achieving hypoglycemia at (0), 30, 60, 90, and $120 \mathrm{~min}$ following the administration of $0.1-0.2 \mathrm{U} / \mathrm{kg}$ i.v. regular insulin for the measurement of cortisol levels. All patients developed symptomatic hypoglycemia with serum glucose levels of $<2.2 \mathrm{mmol} / \mathrm{l}$ during the ITT. Peak cortisol levels of $550 \mathrm{nmol} / \mathrm{l}(20 \mu \mathrm{g} / \mathrm{dl})$ or greater were considered as a normal response to ITT (3).

Serum cortisol levels were measured by RIA with commercially available kits (Active Cortisol RIA, Diagnostic System Laboratories 2100, Webster, TX, USA).
This procedure has an intra- and inter-assay coefficient of variation between $8.4-11.1$ and $9.1-11.5 \%$ respectively. Its sensitivity is $8.3 \mathrm{nmol} / \mathrm{l}(0.3 \mu \mathrm{g} / \mathrm{dl})$.

The study was approved by the local ethics committee, and all patients gave written informed consent.

\section{Statistical analysis}

Statistical analysis was performed with SPSS version 11.0 (SPSS Inc., Chicago, IL, USA) for Windows. The receiver operator characteristic (ROC) curve was used to determine the preoperative basal cortisol cut-off levels in predicting with the best specifity preoperative adrenal insufficiency, according to ITT and postoperative basal cortisol cut-off levels, to detect patients with secondary adrenal insufficiency at 1 st postoperative month.

\section{Results}

\section{Preoperative assessment}

Thirty-four patients had adrenal insufficiency, and 21 patients had a normal cortisol response to ITT preoperatively; ITT could not be performed preoperatively on nine patients. Using ROC analysis to assess the need for dynamic testing, we defined two cut-off values for basal serum cortisol. Patients with a basal cortisol level of $<165 \mathrm{nmol} / \mathrm{l}(6 \mu \mathrm{g} / \mathrm{dl})$ had an insufficient cortisol response to the preoperative ITT (sensitivity: $38.2 \%$, specifity: $100 \%$ in predicting HPA axis insufficiency), and patients with a basal cortisol level $\geq 496 \mathrm{nmol} / \mathrm{l}$ $(18 \mu \mathrm{g} / \mathrm{dl})$ showed a sufficient cortisol response to the preoperative ITT (sensitivity: 47\%, specifity: 100\% in predicting HPA axis sufficiency; Fig. 1).

\section{Postoperative assessment}

Postoperative ITTs were performed on 64 patients. At 1 month, $52 \%$ of patients had similar HPA axis function as they did preoperatively, $18 \%$ recovered, and $14 \%$

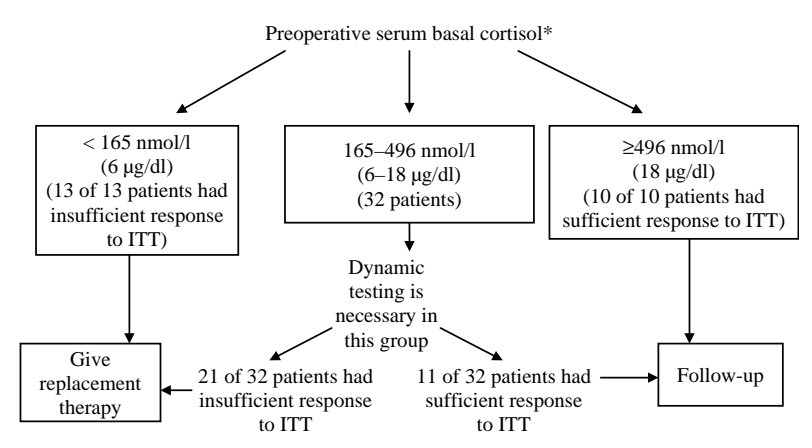

Figure 1 Summary of preoperative hypothalamic-pituitary adrenal axis assessment. *ITT was performed on 55 patients; nine patients (they are not included in this figure) had serum basal cortisol alone. 
Table 1 Preoperative and postoperative adrenal insufficiency at 1 month.

\begin{tabular}{llc}
\hline & Number of patients & $\%$ \\
\hline $\begin{array}{l}\text { Without Al (preop and } \\
\text { postop) }\end{array}$ & 12 & 18.8 \\
$\begin{array}{l}\text { Postop onset Al } \\
\text { Recovered Al }\end{array}$ & 9 & 14 \\
Al (preop and postop) & 12 & 18.8 \\
Preop test not available & 22 (4 postop Al +5 & 34.4 \\
$\quad$ & $\quad$ without AI) & 14 \\
Total & 64 & 100 \\
\hline
\end{tabular}

Al, adrenal insufficiency, according to insulin tolerance test (peak cortisol response $<550 \mathrm{nmol} / \mathrm{l}$ ); preop, preoperative; postop: postoperative.

experienced new-onset secondary adrenal insufficiency (Table 1).

Ten of the $33(30 \%)$ patients with adrenal insufficiency, according to the ITT on the 6th postoperative day, had normal response to the ITT at 1 month. Thirteen of the 31 (42\%) patients who had a normal response to ITT on the 6th postoperative day had adrenal insufficiency at 1 month (Table 2). The positive predictive value of the ITT performed on the 6th postoperative day was 69.7 , and the negative predictive value in predicting adrenal insufficiency at 1 month was $58 \%$.

An ROC analysis was made to define the cut-off values for postoperative basal serum cortisol levels in order to predict postoperative adrenal insufficiency. All patients were considered to have an insufficient cortisol response to the ITT at 1 month if their cortisol levels were $<193 \mathrm{nmol} / \mathrm{l}(7 \mu \mathrm{g} / \mathrm{dl})$ or $220 \mathrm{nmol} / \mathrm{l}(8 \mu \mathrm{g} / \mathrm{dl})$ or $193 \mathrm{nmol} / \mathrm{l}(7 \mu \mathrm{g} / \mathrm{dl})$ or $165 \mathrm{nmol} / \mathrm{l}(6 \mu \mathrm{g} / \mathrm{dl})$ or $83 \mathrm{nmol} / \mathrm{l}(3 \mu \mathrm{g} / \mathrm{dl})$ on the $2 \mathrm{nd}-6$ th postoperative days respectively. The predictive values of postoperative basal cortisol levels are shown in Table 3 .

\section{Discussion}

The need for glucocorticoid replacement therapy before and after pituitary surgery is decided according to the assessment of HPA axis integrity. There is no consensus on which test is best to assess the HPA axis $(10,11)$.

Table 2 Adrenal insufficiency based on insulin tolerance tests (ITTs) on the 6th postoperative day and at 1 month.

\begin{tabular}{lcc}
\hline & $\begin{array}{c}\text { Number of } \\
\text { patients }\end{array}$ & $\%$ \\
\hline Without Al (postop 6th day and & 18 & 28.1 \\
$\quad$ 1st month) & 13 & 20.3 \\
New onset Al at first month & 10 & 15.6 \\
Recovered Al at first month & 23 & 36 \\
Al (postop 6th day and 1st month) & 64 & 100 \\
Total & & \\
\hline
\end{tabular}

AI, adrenal insufficiency according to ITT (peak cortisol response $<550 \mathrm{nmol} / \mathrm{l})$; postop, postoperative.
Although controversy exists regarding the optimal test and optimal time for conducting tests in the postoperative period, the ITT is considered to be the gold standard test and is used as reference in clinical trials $(6,7,9,12,13)$.

In this study, 64 patients with pituitary adenoma undergoing pituitary surgery were evaluated with a preoperative ITT, postoperative daily cortisol measurements and ITTs in the early postoperative period and at 1 month. This study differs from previous studies since patients were prospectively assessed both preoperatively and postoperatively, and we tried to determine the optimal time to measure serum basal cortisol levels.

The preoperative assessment of adrenal sufficiency by basal cortisol measurement as the first-line test has previously been examined. Patients with a basal cortisol level lower than $100 \mathrm{nmol} / \mathrm{l}(3.6 \mu \mathrm{g} / \mathrm{dl})$ are considered to have ACTH deficiency, and glucocorticoid replacement is recommended. A basal cortisol level higher than $450 \mathrm{nmol} / \mathrm{l}(16.3 \mu \mathrm{g} / \mathrm{dl})$ is accepted as a sufficient adrenal response, and cortisol levels between 100 and $450 \mathrm{nmol} / \mathrm{l}(3.6-16.3 \mu \mathrm{g} / \mathrm{dl})$ are recommended for evaluation by dynamic testing (14). According to the results of the preoperative ITTs which were performed on 55 patients in this study, we found that patients with basal serum cortisol levels between 165 and $496 \mathrm{nmol} / \mathrm{l}$ (6-18 $\mu \mathrm{g} / \mathrm{dl})$ required dynamic testing. The majority of previous studies determined the lower cut-off for basal cortisol as $100-110 \mathrm{nmol} / \mathrm{l}(3.6-4 \mu \mathrm{g} / \mathrm{dl})$, but the upper cut-off was found to range between 300 and $494 \mathrm{nmol} / \mathrm{l}(10.8-17.9 \mu \mathrm{g} / \mathrm{dl})(15-18)$. In a metaanalysis of 12 studies, basal cortisol levels $<5 \mu \mathrm{g} / \mathrm{dl}$ $(138 \mathrm{nmol} / \mathrm{l})$ were found to predict HPA insufficiency best, and values $>13 \mu \mathrm{g} / \mathrm{dl}(365 \mathrm{nmol} / \mathrm{l})$ predicted normal HPA function (19). If we had used a cut-off level of $13 \mu \mathrm{g} / \mathrm{dl}$ for HPA axis sufficiency which was suggested by Kazlauskeite et al. (19) 16 patients out of 21 would have been diagnosed correctly in the preoperative period. Of the 21 patients with basal cortisol levels higher than $13 \mu \mathrm{g} / \mathrm{dl}$, five $(24 \%)$ patients had insufficient response to ITT. Similarly, if we had used the suggested cut-off level $(13 \mu \mathrm{g} / \mathrm{dl})$ for basal cortisol for the ITTs conducted on the 6th postoperative day and at 1 month, 21 and $24 \%$ of the patients would have been misdiagnosed as adrenal sufficient. If patients with a postoperative (days 2-6) basal cortisol level higher than $13 \mu \mathrm{g} / \mathrm{dl}$ were assumed to have sufficient HPA axis function at 1 month, $77 \%$ of the patients would have been misdiagnosed as adrenal sufficient. Therefore, the suggested upper cut-off level of $13 \mu \mathrm{g} / \mathrm{dl}$ in the early postoperative period may not be appropriate for the prediction of adrenal insufficiency at 1 month. Basal cortisol levels should be interpreted carefully when evaluating HPA axis sufficiency.

The use of dynamic testing, including the low dose and standard dose ACTH stimulation test, in the early postoperative period has previously been found to be inappropriate, although the $1-\mu \mathrm{g}$ ACTH stimulation test 
Table 3 Prediction of postoperative adrenal insufficiency by postoperative basal cortisol levels.

\begin{tabular}{lcccc}
\hline $\begin{array}{l}\text { Postoperative days and basal } \\
\text { cortisol levels }\end{array}$ & $\begin{array}{c}\text { Positive predictive } \\
\text { value }(\%)\end{array}$ & $\begin{array}{c}\text { Negative predictive } \\
\text { value }(\%)\end{array}$ & $\begin{array}{c}\text { Sensitivity } \\
(\%)\end{array}$ & $\begin{array}{c}\text { Specifity } \\
(\%)\end{array}$ \\
\hline 2nd day $<193 \mathrm{nmol} / \mathrm{l}(7 \mu \mathrm{g} / \mathrm{dl})$ & 100 & 52.9 & 27.3 & 100 \\
3rd day $<220 \mathrm{nmol} / /(8 \mu \mathrm{g} / \mathrm{dl})$ & 100 & 49 & 21 & 100 \\
4th day $<193 \mathrm{nmol} / /(7 \mu \mathrm{g} / \mathrm{dl})$ & 100 & 52 & 27 & 100 \\
5th day $<165 \mathrm{nmol} / /(6 \mu \mathrm{g} / \mathrm{dl})$ & 100 & 56.8 & 26.9 & 17 \\
6th day $<83 \mathrm{nmol} / \mathrm{l}(3 \mu \mathrm{g} / \mathrm{dl})$ & 100 & 48.3 & 100 \\
\hline
\end{tabular}

was found to be better (9). According to our findings, the ITT in the early postoperative period appears to be unnecessary since its positive predictive value was found to be $69.7 \%$ and its negative predictive value in predicting adrenal insufficiency at 1 month was $58 \%$. Therefore, it might be better to postpone dynamic testing with ITT until the end of the 1st postoperative month.

It has been argued that postoperative single or multiple cortisol measurements to evaluate the HPA axis could limit the number of patients undergoing dynamic testing $(20,21)$. Morning serum cortisol a week after pituitary surgery is suggested as a screening test. If serum cortisol is $\leq 100 \mathrm{nmol} / \mathrm{l}(3.6 \mu \mathrm{g} / \mathrm{dl})$, HPA axis insufficiency is present $(6,22-24)$. If the serum cortisol level is $\geq 400$ or $450 \mathrm{nmol} / \mathrm{l}(14.5-16 \mu \mathrm{g} / \mathrm{dl})$, the HPA axis is thought to be sufficient $(6,23-25)$. The minimum cortisol levels which would allow us to predict adrenal insufficiency with $100 \%$ specifity in the very early (2nd and 3rd) postoperative days were found to be higher than the minimum cortisol levels found on the 6th day. Therefore, it should be kept in mind that the cortisol level measured on the 2nd or 3rd postoperative day might not reflect, and may be higher than that at 1 week. Patients with cortisol levels lower than $220-270 \mathrm{nmol} / \mathrm{l}(8-10 \mu \mathrm{g} / \mathrm{dl})$ on the $2 \mathrm{nd}$ or $3 \mathrm{rd}$ postoperative day are discharged and recommended for low-dose glucocorticoid replacement therapy (26-29). The results of this study are consistent with these practices.

Pituitary surgery itself may be responsible, at least in part, for increased serum cortisol levels due to stimulated ACTH secretion. Patients with pituitary adenomas other than Cushing's disease, with an intact HPA axis, have previously been shown to have higher daily urinary free cortisol levels in the postoperative period than patients undergoing surgery for lumbar disc disease (30). The highest levels of urinary cortisol were found on the day of surgery, these declined steadily but remained elevated for a longer period of time than in patients with lumbar disc disease (30). In another study, morning serum cortisol levels were shown to double on the day of pituitary surgery, dropping to normal ranges on the 4th postoperative day (21). Therefore, pituitary surgery itself may cause the release of ACTH, and serum cortisol levels may remain elevated in the early postoperative days.

The role of postoperative morning cortisol levels in detecting adrenal insufficiency has recently been examined. Jayasena et al. reviewed the retrospective data of 36 patients who underwent transsphenoidal surgery for pituitary adenoma followed by the measuring of morning cortisol levels on day 5 and ITT 6 weeks later. Day 5 serum cortisol levels $<111 \mathrm{nmol} / \mathrm{l}$ $(4 \mu \mathrm{g} / \mathrm{dl})$ showed adrenal insufficiency at 6 weeks with $100 \%$ specifity, and cortisol levels higher than $392 \mathrm{nmol} / \mathrm{l}(14.5 \mu \mathrm{g} / \mathrm{dl})$ showed adrenal sufficiency at 6 weeks with $100 \%$ sensitivity and $46 \%$ specifity (8). Marko et al. reviewed the data of 83 pituitary adenoma patients with basal cortisol level measurement on postoperative day 1 in patients without glucocorticoid replacement, and on day 2 in patients who received glucocorticoid replacement during the perioperative period. They suggested a cut-off level of $413 \mathrm{nmol} / \mathrm{l}$ $(15 \mu \mathrm{g} / \mathrm{dl})$ for postoperative steroid supplementation with $80 \%$ sensitivity, $66 \%$ specifity, and a positive predictive value of $96 \%$. At 1-3 months, they reevaluated with a $250-\mu \mathrm{g}$ ACTH stimulation test. They performed an ITT or metyrapone test on only 12 patients with abnormal ACTH stimulation test results. Since the number of patients on whom ITTs were performed were limited $(8,31)$ and lower cut-off values for sufficient cortisol response to ITT (equal or higher than $500 \mathrm{nmol} / \mathrm{l}$ ) were used (8), it is difficult to make a comparison between these studies and the present study.

Cozzi et al. evaluated the cortisol levels of 72 pituitary adenoma patients on the 2 nd postoperative day, and levels lower than $220 \mathrm{nmol} / \mathrm{l}(8 \mu \mathrm{g} / \mathrm{dl})$ were found to show an insufficient response; levels higher than $220 \mathrm{nmol} / \mathrm{l}(8 \mu \mathrm{g} / \mathrm{dl})$ on the 2 nd postoperative day showed sufficient response to the 1- $\mu \mathrm{g}$ ACTH stimulation test at the 6th postoperative week (32). This cutoff level is similar to what we found $(7-8 \mu \mathrm{g} / \mathrm{dl}$ on early postoperative days), but we were unable to conclude that cortisol levels higher than 193-220 nmol/l $(7-8 \mu \mathrm{g} / \mathrm{dl})$ in the early postoperative days would predict sufficient adrenal response to ITT at 1 month.

As mentioned above, the continuation of increased cortisol secretion in some patients after pituitary surgery may limit the ability to define a cut-off value for HPA axis sufficiency $(21,30)$. The sensitivity of the cut-off levels determined in the present study was found to be very low. Therefore, postoperative serum cortisol levels may not be reliable in excluding postoperative adrenal insufficiency at 1 month if they are normal or high. The clinical decision to use glucocorticoid 
replacement seems to be much more important than the measurement of basal cortisol levels unless they are found to be low. It may be more appropriate to carry out definitive dynamic testing at the 1st postoperative month rather than at the 1 st postoperative week.

Differences in the administration of hydrocortisone coverage may have caused discrepancies in the results of serum cortisol levels in different studies. Exogenous glucocorticoids may cause suppression of cortisol (23). In this study, the administration of prednisolone was limited to the day of the operation because there was a probability of suppressing the HPA axis. Although 34 patients had adrenal insufficiency preoperatively in this study, serum basal cortisol levels in the postoperative period were still high. Patients had glucocorticoid replacement just on the day of the operation, and daily cortisol measurements started on the 2nd postoperative day allowing a time period long enough for the clearence of any exogenous prednisolone which could account for elevated cortisol levels on the 2 nd3rd postoperative days; there were also patients who did not receive glucocorticoids perioperatively.

In conclusion, in patients with pituitary adenoma, preoperative ITT should be reserved for selected patients with cortisol levels between 165 and $496 \mathrm{nmol} / \mathrm{l}$ $(6-18 \mu \mathrm{g} / \mathrm{dl})$. An ITT performed shortly after surgery is not reliable in predicting long-term HPA axis failure. Postoperative serum basal cortisol levels may help to limit the number of patients undergoing dynamic testing at the 1st postoperative month, but it should be kept in mind that basal cortisol cut-offs may change during the early follow-up. If dynamic testing is required, it is reasonable to wait until the end of the first month.

\section{Declaration of interest}

The authors declare that there is no conflict of interest that could be perceived as prejudicing the impartiality of the research reported.

\section{Funding}

This research did not receive any specific grant from any funding agency in the public, commercial, or not-for-profit sector.

\section{References}

1 Fish HR, Chernow B \& O'Brian JT. Endocrine and neurophysiologic responses of the pituitary to insulin-induced hypoglycemia: a review. Metabolism 198635 763-780.

2 Grinspoon SK \& Biller BM. Clinical review 62: laboratory assessment of adrenal insufficiency. Journal of Clinical Endocrinology and Metabolism 199479 923-931.

3 Plumpton FS \& Besser GM. The adrenocortical response to surgery and insulin-induced hypoglycaemia in corticosteroid-treated and normal subjects. British Journal of Surgery 196956 216-219.

4 Pfeifer M, Kanc K, Verhovec R \& Kocijancic A. Reproducibility of the insulin tolerance test (ITT) for assessment of growth hormone and cortisol secretion in normal and hypopituitary adult men. Clinical Endocrinology 200154 17-22.
5 Vestergaard P, Hoeck HC, Jakobsen PE \& Laurberg P. Reproducibility of growth hormone and cortisol responses to the insulin tolerance test and the short ACTH test in normal adults. Hormone and Metabolic Research 199729 106-110.

6 Courtney CH, McAllister AS, McCance DR, Bell PM, Hadden DR, Leslie H, Sheridan B \& Atkinson AB. Comparison of one week $0900 \mathrm{~h}$ serum cortisol, low and standard dose synacthen tests with a 4 to 6 week insulin hypoglycaemia test after pituitary surgery in assessing HPA axis. Clinical Endocrinology 200053 431-436.

7 Courtney CH, McAllister AS, Bell PM, McCance DR, Leslie H, Sheridan B \& Atkinson AB. Low- and standard-dose corticotropin and insulin hypoglycemia testing in the assessment of hypothalamic-pituitary-adrenal function after pituitary surgery. Journal of Clinical Endocrinology and Metabolism 200489 17121717.

8 Jayasena CN, Gadhvi KA, Gohel B, Martin NM, Mendoza N, Meeran K \& Dhillo WS. Day 5 morning serum cortisol predicts hypothalamic-pituitary-adrenal function after transsphenoidal surgery for pituitary tumors. Clinical Chemistry 2009 55 972-977.

9 Dokmetas HS, Colak R, Kelestimur F, Selcuklu A, Unluhizarci K \& Bayram F. A comparison between the 1-microg adrenocorticotropin (ACTH) test, the short ACTH (250 microg) test, and the insulin tolerance test in the assessment of hypothalamopituitary-adrenal axis immediately after pituitary surgery. Journal of Clinical Endocrinology and Metabolism $2000 \mathbf{8 5}$ 3713-3719.

10 Clayton RN. Short synacthen test versus insulin stress test for assessment of the hypothalamo [correction of hypothalmo]pituitary-adrenal axis controversy revisited. Clinical Endocrinology 199644 147-149.

11 Stewart PM, Corrie J, Seckl JR, Edwards CR \& Padfield PL. A rational approach for assessing the hypothalamo-pituitaryadrenal axis. Lancet 19881 1208-1210.

12 Courtney CH, McAllister AS, McCance DR, Hadden DR, Leslie H, Sheridan B \& Atkinson AB. The insulin hypoglycaemia and overnight metyrapone tests in the assessment of the hypothalamic-pituitary-adrenal axis following pituitary surgery. Clinical Endocrinology 200053 309-312.

13 Reynolds RM, Stewart PM, Seckl JR \& Padfield PL. Assessing the HPA axis in patients with pituitary disease: a UK survey. Clinical Endocrinology 200664 82-85.

14 Pereira 0 \& Bevan JS. Preoperative assessment for pituitary surgery. Pituitary 200811 347-351.

15 Deutschbein T, Unger N, Mann K \& Petersenn S. Diagnosis of secondary adrenal insufficiency in patients with hypothalamicpituitary disease: comparison between serum and salivary cortisol during the high-dose short synacthen test. European Journal of Endocrinology 2009160 9-16.

16 Erturk E, Jaffe CA \& Barkan AL. Evaluation of the integrity of the hypothalamic-pituitary-adrenal axis by insulin hypoglycemia test. Journal of Clinical Endocrinology and Metabolism $1998 \mathbf{8 3}$ 2350-2354.

17 Hagg E, Asplund K \& Lithner F. Value of basal plasma cortisol assays in the assessment of pituitary-adrenal insufficiency. Clinical Endocrinology 198726 221-226.

18 Jones SL, Trainer PJ, Perry L, Wass JA, Bessser GM \& Grossman A. An audit of the insulin tolerance test in adult subjects in an acute investigation unit over one year. Clinical Endocrinology 199441 123-128.

19 Kazlauskaite R, Evans AT, Villabona CV, Abdu TA, Ambrosi B, Atkinson $\mathrm{AB}$, Choi $\mathrm{CH}$, Clayton $\mathrm{RN}$, Courtney $\mathrm{CH}$, Gonc EN, Maghnie M, Rose SR, Soule SG \& Tordjman K. Corticotropin tests for hypothalamic-pituitary-adrenal insufficiency: a meta analysis. Journal of Clinical Endocrinology and Metabolism 200893 4245-4253.

20 Auchus RJ, Shewbridge RK \& Shepherd MD. Which patients benefit from provocative adrenal testing after transsphenoidal pituitary surgery? Clinical Endocrinology 199746 21-27. 
21 Hout WM, Arafah BM, Salazar R \& Selman W. Evaluation of the hypothalamic-pituitary-adrenal axis immediately after pituitary adenomectomy: is perioperative steroid therapy necessary? Journal of Clinical Endocrinology and Metabolism $1988 \mathbf{6 6}$ 1208-1212.

22 Inder WJ \& Hunt PJ. Glucocorticoid replacement in pituitary surgery: guidelines for perioperative assessment and management. Journal of Clinical Endocrinology and Metabolism $2002 \mathbf{8 7}$ 2745-2750.

23 Klose M, Lange M, Kosteljanetz M, Poulsgaard L \& FeldtRasmussen U. Adrenocortical insufficiency after pituitary surgery: an audit of the reliability of the conventional short synacthen test. Clinical Endocrinology 200563 499-505.

24 Watts NB \& Tindall GT. Rapid assessment of corticotropin reserve after pituitary surgery. Journal of the American Medical Association $1988259708-711$.

25 Gleeson HK, Walker BR, Seckl JR \& Padfield PL. Ten years on: safety of short synacthen tests in assessing adrenocorticotropin deficiency in clinical practice. Journal of Clinical Endocrinology and Metabolism $2003 \mathbf{8 8} 2106-2111$.

26 Ausiello JC, Bruce JN \& Freda PU. Postoperative assessment of the patient after transsphenoidal pituitary surgery. Pituitary 200811 391-401.

27 Dumont AS, Nemergut EC, Jane JA Jr \& Laws ER Jr. Postoperative care following pituitary surgery. Journal of Intensive Care Medicine 200520 127-140.
28 Hensen J, Henig A, Fahlbusch R, Meyer M, Boehnert M \& Buchfelder M. Prevalence, predictors and patterns of postoperative polyuria and hyponatraemia in the immediate course after transsphenoidal surgery for pituitary adenomas. Clinical Endocrinology $1999 \mathbf{5 0} 431-439$.

29 Vance ML. Perioperative management of patients undergoing pituitary surgery. Endocrinology and Metabolism Clinics of North America 200332 355-365.

30 Kristof RA, Wichers M, Haun D, Redel L, Klingmuller D \& Schramm J. Peri-operative glucocorticoid replacement therapy in transsphenoidal pituitary adenoma surgery: a prospective controlled study. Acta Neurochirurgica 2008150 329-335.

31 Marko NF, Gonugunta VA, Hamrahian AH, Usmani A, Mayberg MR \& Weil RJ. Use of morning serum cortisol level after transsphenoidal resection of pituitary adenoma to predict the need for long-term glucocorticoid supplementation. Journal of Neurosurgery $2009111540-544$.

32 Cozzi R, Lasio G, Cardia A, Felisati G, Montini M \& Attanasio R. Perioperative cortisol allows to predict hypothalamus-pituitary-adrenal status in clinically non-functioning pituitary adenomas. Journal of Endocrinological Investigation $200932460-464$.

Received 31 May 2010

Accepted 8 June 2010 